\title{
WERYFIKACJA KWALIFIKACJI KANDYDATÓW NA BIEGEYCH SĄDOWYCH Z DZIEDZINY KRYMINALISTYKI NA PRZYKŁADZIE ANALIZY DANYCH DOTYCZĄCYCH BIEGEYCH SĄDOWYCH WPISANYCH NA LISTE PROWADZONĄ PRZEZ PREZESA SĄDU OKRĘGOWEGO W POZNANIU
}

\section{WPROWADZENIE}

Celem artykułu jest ustalenie modelu weryfikacji kwalifikacji kandydatów na biegłych sądowych istniejącego w praktyce. Model ten ukazano na przykładzie okręgu poznańskiego. Artykuł przygotowano na podstawie badań własnych akt osobowych biegłych sądowych z dziedziny kryminalistyki wpisanych na listę prowadzoną przez Prezesa Sądu Okręgowego w Poznaniu. Problem sposobu weryfikacji kwalifikacji biegłych sądowych jest w dalszym ciagu aktualny i szeroko dyskutowany w literaturze przedmiotu. Dotychczas nie wypracowano w systemie prawnym nowego sposobu weryfikacji kwalifikacji biegłych sądowych, a aktualnie obowiązujący system weryfikacji tych kwalifikacji ma prawdopodobnie tyle samo zwolenników co przeciwników. Problem ten - rzecz naturalna - współtowarzyszy problemowi nowej ustawy o biegłych sądowych, która do tej pory nie doczekała się uchwalenia i tym samym wprowadzenia w życie. Prace nad ustawą trwaja, a sam projekt ustawy nie ma ciagle ostatecznego kształtu ${ }^{1}$. W tym stanie rzeczy warto podjąć rozważania, czy obecny stan prawny co do sposobu weryfikacji kwalifikacji biegłych sądowych sprawdza się w praktyce i ewentualnie, jak należy ten system usprawnić.

${ }^{1}$ Zob. Aktualności, Pismo Zastępcy Dyrektora Departamentu Zawodów Prawniczych i Dostępu do Pomocy Prawnej Grażyny Kołodziejskiej z 8 kwietnia 2016 r. do Romualda Tomczyka Prezesa Zarządu Stowarzyszenia Rzeczoznawców Ekonomicznych w Częstochowie, http://www. sadowibiegli.pl/aktual/2016/ms1b.pdf [dostęp: 26.04.2016]. 


\section{USTAWOWY MODEL WERYFIKACJI KWALIFIKACJI KANDYDATÓW NA BIEGEYCH SĄDOWYCH}

Biegły jest osobą posiadająca wiadomości specjalne, wezwaną przez organ procesowy do zbadania i wyjaśnienia istotnych dla rozstrzygnięcia sprawy okoliczności, których poznanie wymaga wiadomości specjalnych z zakresu nauki, sztuki, techniki lub rzemiosła. Biegłym jest również osoba wezwana w celu wydania opinii co do okoliczności istotnej w danej sprawie do jej wyjaśnienia ${ }^{2}$. $\mathrm{Na}$ gruncie procedury cywilnej oraz karnej biegły jest źródłem dowodowym, a rezultat jego pracy stanowi dowód w sprawie (opinia biegłego) ${ }^{3}$. W obydwu procedurach funkcjonują dwa pojęcia odnoszące się do biegłych - biegły sądowy oraz biegły $a d h o c^{4}$. Obydwaj biegli sa jednakowo uprawnieni do wydania opinii w postępowaniu cywilnym albo karnym. Różnica w ich funkcjonowaniu dotyczy jedynie sposobu powołania do pełnienia funkcji biegłego. W przypadku biegłych sądowych organ procesowy wiedzę o osobie biegłego i jego kwalifikacjach czerpie $\mathrm{z}$ listy biegłych sądowych prowadzonej przez prezesa sądu okręgowego. Biegły ad hoc powoływany jest przez organ procesowy spośród specjalistów w danej dziedzinie, jednakże niewpisanych na listę biegłych sądowych. Do powołania w procesie biegłego ad hoc dochodzi zazwyczaj wtedy, kiedy na liście biegłych sądowych brak ekspertów z danej dziedziny wiedzy, co do której niezbędne jest pozyskanie opinii w procesie.

Oprócz instytucji biegłych sądowych oraz biegłych ad hoc obydwie procedury przewiduja opinie instytucji naukowych lub specjalistycznych. Z uwagi na zakres niniejszego artykułu zagadnienie wydania opinii przez biegłego lub biegłych z instytucji naukowej lub specjalistycznej celowo pominięto ${ }^{5}$.

Powoływanie biegłych sądowych w obecnym systemie prawnym regulują przepisy rozporządzenia Ministra Sprawiedliwości z 24 stycznia 2005 r. w sprawie biegłych sądowych ${ }^{6}$. W $\S 1$ ust. 1 rozporządzenia ustawodawca nałożył na prezesa sądu okręgowego obowiązek ustanawiania biegłych sądowych. W $§ 3$ ust. 1 i 2 rozporządzenia ustawodawca zobowiązał prezesa sądu okrę-

${ }^{2}$ Zob. S. Kalinowski, Biegty $i$ jego opinia, Wyd. Centralne Laboratorium Kryminalistyczne, Warszawa 1994, s. 78; T. Tomaszewski, Dowód z opinii biegłego w polskim procesie karnym, wyd. 2, Instytut Ekspertyz Sądowych im. Prof. dra Jana Sehna w Krakowie, Kraków 2000, s. 9; K. Knoppek, Dowód z opinii biegtego, w: T. Wiśniewski (red.), Postępowanie procesowe przed sqdem pierwszej instancji, cz. 2, Wolters Kluwer, Warszawa 2016, s. 399-401; S. Rejman, Dowód $z$ opinii biegłego $w$ postępowaniu cywilnym, Wydawnictwo Prawnicze, Warszawa 1973, s. 6-7.

${ }^{3}$ Zob. S. Waltoś, P. Hofmański, Proces karny. Zarys systemu, wyd. 12, Wolters Kluwer, Warszawa 2016, s. 350; T. Nowak, Dowód $z$ opinii biegtego $w$ polskim procesie karnym, WN UAM, Poznań 1966, s. 44.

${ }^{4}$ Zob. art. 195 ustawy z 6 czerwca 1997 r. - Kodeks postępowania karnego (Dz. U. Nr 89, poz. 555 ze zm.); art. 278 ustawy z 17 listopada 1964 r. - Kodeks postępowania cywilnego (Dz. U. Nr 43, poz. 296 ze zm.).

${ }^{5}$ Szerzej zob. S. Kalinowski, Biegty $i$ jego opinia..., s. 83-85; idem, Biegty w postepowaniu karnym. Zagadnienia wybrane, Wydawnictwo Prawnicze, Warszawa 1967, s. 16-17; idem, Biegty. Ogólne wiadomości prawa dowodowego. Prawa i obowiazki biegtego, biegty w postęowaniu karnym, Wydawnictwo Prawnicze, Warszawa 1973, s. 101-103; M. Rybarczyk, Biegty w postepowaniu cywilnym. Opinia. Odpowiedzialność. Wynagrodzenie, C. H. Beck, Warszawa 2001, s. 12-13.

${ }^{6}$ Dz. U. 2005, Nr 15, poz. 133. 
gowego do zasięgnięcia opinii zakładu pracy w przypadku pozostawania przez kandydata na biegłego w stosunku zatrudnienia lub organizacji zawodowej, do której należy dana osoba, w przypadku wykonywania przez tę osobę wolnego zawodu. W $§ 12$ ust. 1 rozporządzenia ustawodawca wskazał cechy, jakimi powinien charakteryzować się kandydat na biegłego sądowego. Zgodnie z $§ 12$ ust. 2 rozporządzenia posiadanie wiadomości specjalnych powinno być wykazane dokumentami lub innymi dowodami.

Resumując, prezes sądu okręgowego, analizując kompetencje kandydata na biegłego, ma za zadanie dokonać następujących czynności:

1) ustalić, czy kandydat wyraził zgodę na ustanowienie go biegłym;

2) ustalić, wiek kandydata na biegłego, tj. czy kandydat na biegłego ukończył 25 rok życia;

3) ustalić, czy kandydat korzysta z pełni praw cywilnych i obywatelskich;

4) zasięgnać opinii zakładu pracy w przypadku pozostawania przez kandydata na biegłego w stosunku zatrudnienia lub organizacji zawodowej, do której należy dana osoba, w przypadku wykonywania przez tę osobę wolnego zawodu;

5) sprawdzić, czy osoba daje gwarancję należytego wykonywania obowiązków biegłego;

6) sprawdzić, czy kandydat na biegłego posiada teoretyczne i praktyczne wiadomości specjalne warunkujące podjęcie przez niego funkcji biegłego z danej dziedziny wiedzy.

Wytyczne ustawodawcy wskazane w pkt 1-4 wydają się stosunkowo łatwe w realizacji. Kandydat na biegłego składa zazwyczaj do prezesa sądu okręgowego pisemny wniosek o ustanowienie go biegłym sądowym i sam wniosek już można uznać za zgodę na ustanowienie biegłym sądowym.

Ustalenie wieku kandydata na biegłego również nie powinno być problemem. Zazwyczaj wiek ten wynika z przedłożonych przez kandydata dokumentów, w tym odpisu dyplomu ukończenia studiów wyższych.

Co rozumie się przez korzystanie z pełni praw cywilnych i obywatelskich, nie zostało wyjaśnione przez ustawodawcę. Wobec tego odnieść należy się do aktów prawnych regulujących te kwestie. Źródeł praw cywilnych obywatela należy szukać w Kodeksie cywilnym ${ }^{7}$, w regulacjach dotyczących zdolności do czynności prawnych oraz jej braku ${ }^{8}$. Prawa obywatelskie reguluje Konstytucja Rzeczypospolitej Polskiej ${ }^{9}$. W rozdziale II Konstytucji ustawodawca wskazał na wolności, prawa oraz obowiązki człowieka i obywatela. Prawami obywatelskimi zgodnie z Konstytucją są prawa polityczne i ekonomiczne, socjalne oraz kulturalne. Najważniejszymi spośród nich są prawa polityczne obywateli, a wśród nich m.in. czynne oraz bierne prawo wyborcze ${ }^{10}$.

${ }^{7}$ Ustawa z 23 kwietnia 1964 r. - Kodeks cywilny, t.jedn.: Dz. U. 2016, poz. 380 (dalej jako: k.c.).

${ }^{8}$ Zob. art. $11-12$ i 15 k.c.

${ }^{9}$ Dz. U. 1997, Nr 78, poz. 483 ze zm.

${ }^{10}$ Ponadto są to m.in.: prawo dostępu do służby publicznej, prawo do uzyskiwania informacji o działalności organów władzy publicznej oraz osób pełniących funkcje publiczne, prawo do składania petycji, wniosków i skarg w interesie publicznym, własnym lub innej osoby za jej zgodą do organów władzy publicznej oraz do organizacji i instytucji społecznych w związku z wy- 
Jak wynika z powyższego, z punktu widzenia weryfikacji kandydata na biegłego sądowego, istotne będzie, czy kandydat na biegłego korzysta z pełni praw cywilnych, a innymi słowy - czy posiada pełną zdolność do czynności prawnych oraz czy posiada pełnię praw publicznych, w tym wyborczych. $\mathrm{O}$ spełnieniu ze strony kandydata na biegłego tych kryteriów stanowić będzie brak w stosunku do kandydata na biegłego prawomocnego orzeczenia orzekającego ubezwłasnowolnienie częściowe lub całkowite oraz brak prawomocnego orzeczenia sądowego pozbawiającego go praw publicznych ${ }^{11}$.

Zasięgnięcie opinii zakładu pracy lub organizacji zawodowej nie powinno nastręczać problemów. W przypadku uzyskania informacji - zazwyczaj ze składanego przez kandydata życiorysu - co do zatrudnienia lub wykonywania wolnego zawodu i bycia członkiem organizacji zawodowej prezes obowiązany jest pozyskać opinię pracodawcy albo organizacji. Choć ustawodawca tego nie zastrzega, to nie ulega wątpliwości, że opinia ta, dla skutecznego ustanowienia kandydata biegłym sądowym, powinna być pozytywna. Tylko pozytywne zdanie o kandydacie ze strony jego dotychczasowego pracodawcy lub organizacji go zrzeszającej może stanowić o tym, iż kandydat na biegłego daje gwarancję należytego wykonywania obowiązḱw biegłego. Ktoś, kto jest nierzetelnym pracownikiem lub niewłaściwie wykonuje swoje obowiązki zawodowe, wykonując wolny zawód, nie może dawać gwarancji należytego wykonywania obowiązków biegłego. Innymi słowy, nie rokuje dobrze na przyszłość.

Gwarancja należytego wykonywania obowiązków biegłego to nic innego jak gwarancja, że dana osoba będzie wywiązywać się z nałożonych na nią obowiązków, tj. będąc powołanym w danej sprawie biegłym, złoży opinię, a opinia ta będzie złożona $\mathrm{w}$ terminie, zgodnie ze stanem wiedzy i umiejętności biegłego oraz stosownie do aktualnego stanu nauki. W zasadzie brak jednoznacznych obiektywnych kryteriów pozwalajacych stwierdzić, że dana osoba będzie należycie sprawować powierzona jej funkcję poza tymi, które odnoszą się do przeszłości tej osoby. Jak wskazano powyżej, jednym z wyznaczników tej gwarancji może być wzorowe wywiązywanie się przez daną osobę z obowiązków pracowniczych lub należyte wykonywanie wolnego zawodu. Stwierdzić to można na podstawie jednoznacznie pozytywnej opinii pracodawcy lub organizacji zawodowej. Orzecznictwo sądowe dostarcza jeszcze innych wyznaczników gwarancji należytego wykonywania obowiązków biegłego - wcześniejszą niekaralność, i to zarówno za wykroczenia ${ }^{12}$, jak i przestępstwa ${ }^{13}$. Orzecznictwo Sądu

konywanymi przez nie zadaniami zleconymi z zakresu administracji publicznej (zob. art. 60-63 Konstytucji).

${ }^{11}$ Pozbawienie praw publicznych jest środkiem karnym, orzekanym na podstawie art. 40 ustawy z 6 czerwca 1997 r. - Kodeks karny, Dz. U. 1997, Nr 88, poz. 553 ze zm. (dalej: k.k.). Obejmuje ono utratę czynnego i biernego prawa wyborczego do organu władzy publicznej, organu samorządu zawodowego lub gospodarczego, utratę prawa do udziału w sprawowaniu wymiaru sprawiedliwości oraz do pełnienia funkcji w organach i instytucjach państwowych i samorządu terytorialnego lub zawodowego, jak również utratę posiadanego stopnia wojskowego i powrót do stopnia szeregowego; pozbawienie praw publicznych obejmuje ponadto utratę orderów, odznaczeń i tytułów honorowych oraz utratę zdolności do ich uzyskania w okresie trwania pozbawienia praw.

${ }_{12}$ Zob. wyrok WSA w Warszawie z 10 lipca 2007 r. w sprawie, VI SA/Wa 786/07, Lex, nr 394415.

${ }^{13}$ Zob. wyrok WSA w Warszawie z 11 stycznia 2006 r., VI SA/Wa 1976/05, Lex, nr 206569. 
Najwyższego nasuwa ponadto wnioski, że każda negatywna informacja co do przeszłości kandydata na biegłego zarówno z jego sfery życia prywatnego, jak i zawodowego może stanowić o tym, iż kandydat nie daje gwarancji należytego wykonywania obowiązków biegłego ${ }^{14}$.

Ostatnim z wymogów jest sprawdzenie, czy kandydat na biegłego posiada teoretyczne i praktyczne wiadomości specjalne warunkujące podjęcie przez niego funkcji biegłego z danej dziedziny wiedzy. Wiadomości teoretyczne to nic innego jak teoretyczne przygotowanie ze strony kandydata na biegłego co do pełnienia funkcji biegłego $\mathrm{z}$ danej dziedziny wiedzy. Emanacja tego jest posiadane przez kandydata na biegłego odpowiedniego wykształcenia, i to zarówno co do poziomu, jak i rodzaju tego wykształcenia ${ }^{15}$.

Nie ulega wątpliwości, że najbardziej pożądanym z punktu widzenia funkcji biegłego sądowego jest wykształcenie wyższe oraz kierunkowe co do specjalności, w której kandydat wnosi o ustanowienie biegłym sądowym. Rozporzadzenie o biegłych sądowych nie zawiera jednakże ku temu żadnych ograniczeń ani nie wartościuje poziomów i rodzajów wykształcenia w żaden sposób. Tym samym można wyobrazić sobie biegłego sądowego z wykształceniem średnim lub zawodowym. Ważne jest jednak, aby wykształcenie korespondowało ze specjalnościa, z której daną osobę ustanowiono biegłym sądowym.

Uzupełnienie kierunku wykształcenia mogą stanowić kursy zawodowe ${ }^{16}$ i specjalistyczne oraz szkolenia podnoszące poziom wiedzy i umiejętności kandydata. $\mathrm{O}$ ile nazwa kursu zawodowego zakończonego egzaminem państwowym daje możliwość w miarę realnej oceny poziomu wiedzy i umiejętności kandydata, o tyle sama nazwa szkolenia niewiele o tym mówi. Dla rzetelnej oceny poziomu wiedzy i umiejętności nabytej przez kandydata na kursie specjalistycznym konieczne jest dokonanie analizy programu takiego kursu, jak również oceny, czy nabyta wiedza i umiejętności są wystarczające do zdobycia wiedzy i praktyki w danej dziedzinie. Szkolenia różnią się między sobą liczbą godzin teoretycznych i praktycznych, poziomem przekazywanej wiedzy oraz sposobem weryfikacji wiedzy i umiejętności zdobytych w trakcie szkolenia. Zazwyczaj poziom nabytej wiedzy i umiejętności nie jest weryfikowany przez organizatora szkolenia w ogóle. Trudno zatem osobom postronnym weryfikować jakość szkolenia.

Nie ulega jednak wątpliwości, że ocena umiejętności teoretycznych i praktycznych kandydata na biegłego jest najtrudniejsza i w zasadzie bez posiada-

${ }^{14}$ W wyroku WSA w Warszawie z 10 lipca 2007 r., VI SA/Wa 786/07, stwierdził, że „przez rękojmię należytego wykonywania obowiązków należy rozumieć zespół cech, zdarzeń i okoliczności dotyczących danej osoby, zarówno ze sfery jej życia prywatnego, jak też zawodowego, składających się na wizerunek tej osoby jako osoby zaufania publicznego. Trafnie przytoczył organ wyrok NSA z 13 kwietnia 2000 r., II SA 115/00 i zawartą w nim tezę, że „osoba biegłego nie może być dotknięta żadną skaza, która podważałaby zaufanie do niej” (Lex, nr 394415). Por. wyrok WSA z 18 października 2006 r., VI SA/Wa 1553/06, Lex, nr 264553.

${ }_{15}$ Poziomy, rodzaje i profile kształcenia określa rozporządzenie Rady Ministrów z 6 maja 2003 r. w sprawie Polskiej Klasyfikacji Edukacji, Dz. U. 2003, Nr 98, poz. 895.

${ }^{16}$ Klasyfikacja zawodów szkolnictwa zawodowego oraz kursów szkolnictwa zawodowego dokonana została w rozporządzeniu Ministra Edukacji Narodowej z 23 grudnia 2011 r. w sprawie klasyfikacji zawodów szkolnictwa zawodowego, Dz. U. 2012, poz. 7 ze zm. 
nia odpowiedniej wiedzy z każdej z dziedzin, z których powoływani są biegli, praktycznie niemożliwa do zrealizowania. Ustawodawca jednakże wyraźnie nałożył na prezesa sądu okręgowego obowiązek weryfikacji wiedzy i umiejętności kandydata pod kątem przydatności do roli biegłego. Pytanie brzmi: jak tego dokonać?

\section{KWALIFIKACJE BIEGEYCH SĄDOWYCH Z DZIEDZINY KRYMINALISTYKI ORAZ SPOSÓB ICH WERYFIKACJI NA PRZYKŁADZIE OKRĘGU POZNAŃSKIEGO}

\section{Specjalność biegłych sądowych}

Badaniom poddano akta osobowe 35 biegłych z dziedziny kryminalistyki wpisanych na listę prowadzoną przez Prezesa Sądu Okręgowego w Pozna$\mathrm{niu}^{17}$. Zestawienie specjalności biegłych wpisanych na listę biegłych sądowych w dziedzinie „Kryminalistyka” przedstawia tabela 1.

Tabela 1

Zestawienie specjalności biegłych ${ }^{18}$

\begin{tabular}{|c|l|c|}
\hline Lp. & \multicolumn{1}{|c|}{ Specjalność bieglych } & Liczba bieglych \\
\hline 1. & Daktyloskopia & 6 \\
\hline 2. & Badania dokumentów & 17 \\
\hline 3. & Traseologia & 1 \\
\hline 4. & Mechanoskopia i rekonstrukcja wypadków drogowych & 8 \\
\hline 5. & Badania chemiczne & 2 \\
\hline 6. & Badania biologiczne & 2 \\
\hline 7. & Badania fonoskopijne: badania odsłuchowe & 1 \\
\hline
\end{tabular}

Źródło: opracowanie własne.

Jak wynika z tabeli 1, większość biegłych wpisana na listę biegłych sądowych z dziedziny kryminalistyki to eksperci ze specjalności badań dokumentów. Spośród nich 2 biegłych zajmuje się wyłącznie technicznokryminalistycznymi badaniami dokumentów, a 9 biegłych zajmuje się wyłącznie klasycznymi badaniami pisma.

17 Byli to jednocześnie wszyscy biegli wpisani na listę biegłych sądowych na dzień 17 marca 2016 r.

18 Liczba biegłych (37) przedstawiona w tabeli 1 różni się od ogólnej liczby biegłych wpisanych na listę biegłych sądowych z tej dziedziny (35), albowiem jeden z biegłych wpisanych na listę specjalizuje się jednocześnie w traseologii oraz mechanoskopii, a drugi z biegłych obok badań pismoznawczych zajmuje się również badaniami odsłuchowymi nagrań. Dodatkowo badania nie objęły biegłych z innych dziedzin kryminalistyki, a mianowicie badań broni palnej, albowiem biegli z tej dziedziny widnieją na liście biegłych sądowych jako biegli z odrębnej od kryminalistyki specjalności, tj. „Broń palna”. Zob. Lista biegłych sądowych [dot. SO w Poznaniu], http://www.poznan. so.gov.pl/att/Lista_bieg_ych_s_dowych_11_kwiecie__2016.pdf [dostęp: 28.04.2016]. 


\section{Wiek biegłych i zgoda na ustanowienie biegłym}

Wyniki przeprowadzonych badań wskazuja, że wszyscy biegli wpisani na listę biegłych sądowych w momencie dokonania wpisu ukończyli 25 rok życia. Fakt ten wynikał ze złożonego przez biegłych życiorysu oraz kopii dyplomu ukończenia studiów wyższych, które były załączone do wniosku o ustanowienie biegłym sądowym. Jednocześnie wszyscy biegli zostali wpisani na listę biegłych sądowych na podstawie ich własnego wniosku.

\section{Korzystanie z pelni praw cywilnych i obywatelskich oraz gwarancja należytego wykonywania obowiązków biegłego}

Weryfikacja spełnienia przez kandydata na biegłego warunku polegajacego na korzystaniu z pełni praw cywilnych i obywatelskich oraz gwarancji należytego wykonywania obowiązków biegłego była dokonywana na podstawie informacji z Krajowego Rejestru Karnego ${ }^{19}$. Prezes Sądu Okręgowego w Poznaniu wymagał ponadto złożenia przez kandydatów na piśmie oświadczenia co do korzystania z pełni praw cywilnych oraz obywatelskich. Wszyscy kandydaci złożyli pisemne oświadczenia o korzystaniu z pełni praw cywilnych i obywatelskich oraz żaden nie figurował w Krajowym Rejestrze Karnym.

Siłą rzeczy były to jedyne realne i szybkie sposoby weryfikacji tych danych. Obecnie brak centralnego rejestru osób ubezwłasnowolnionych, z którego można pozyskać informację co do sytuacji prawnej kandydata na biegłego ${ }^{20}$. Należy dodatkowo wskazać, że dane co do skazania ulegają usunięciu z rejestru $^{21}$ po upływie terminów określonych przepisami prawa ${ }^{22}$. O ile zatarcie skazania nie kłóci się z wymogiem korzystania przez kandydata na biegłego z pełni praw obywatelskich ${ }^{23}$, o tyle może pozostawać w sprzeczności z wymogiem dawania ze strony kandydata gwarancji należytego wykonywania obowiązków biegłego. Osoba, która choćby raz została skazana za przestępstwo, przestępstwo skarbowe lub choćby wykroczenie, nie może bowiem cieszyć się nieposzkalowaną opinią. Nie daje tym samym gwarancji należytego wykonywania obowiązków biegłego.

$\mathrm{W}$ badanych sprawach $\mathrm{w}$ sumie kandydaci złożyli w toku postępowania kwalifikacyjnego 32 opinie pracodawców. Wszystkie przedłożone opinie o kandydatach były pozytywne. Brak było zatem przesłanek do tego, aby

\footnotetext{
${ }^{19}$ Rejestr prowadzony jest na podstawie przepisów ustawy z 24 maja 2000 r. o Krajowym Rejestrze Karnym, Dz. U. 2015, poz. 1036 ze zm. (dalej jako: ustawa o Krajowym Rejestrze Karnym).

${ }^{20}$ Choć $\mathrm{w}$ praktyce pojawiły się takie pomysły. Zob. Ubezwłasnowolnieni mogą trafić do rejestru, http://www.lex.pl/czytaj/-/artykul/ubezwlasnowolnieni-moga-trafic-do-rejestru [dostęp: 28.04.2016].

${ }^{21}$ Zob. art. 14 ustawy o Krajowym Rejestrze Karnym.

${ }^{22}$ Zob. art. 106-108 k.k.

${ }^{23}$ Skazanie po zatarciu uważa się za niebyłe. Zob. art. 106 k.k.
} 
uznać, że którykolwiek z kandydatów nie spełniał ww. kryterium ustanowienia biegłym. Wskazać dodatkowo należy, że 27 opinii spośród 32 opinii pracodawców zostało wydanych przez Komendanta Wojewódzkiego Policji w Poznaniu lub naczelników wydziałów policji odpowiedzialnych za prowadzenie kadr. Spośród opinii pozostałych pracodawców 2 opinie pochodziły od przedsiębiorstwa prywatnego oraz po jednej opinii ze szkoły, banku i szpitala.

Dwie osoby nie były nigdzie zatrudnione ani nie wykonywały wolnego zawodu - tym samym nie przedstawiły opinii. Można tym samym postawić pytanie, czy w związku z tym weryfikacja co do tych osób mogła być przeprowadzona rzetelnie. Wypracowana przez Prezesa Sądu Okręgowego w Poznaniu procedura weryfikacyjna, zwłaszcza w ostatnich latach, zakłada - obok realizacji ustawowego obowiązku przedłożenia opinii pracodawcy lub organizacji - konieczność pozyskania opinii innych organizacji zrzeszajacych kandydata lub działających w tożsamym zakresie specjalności. Tak też było i w tych przypadkach. Co do jednego z kandydatów rekomendację co do jego osoby przedłożyło stowarzyszenie zrzeszające kandydata, natomiast co do drugiego - zwrócono się o opinię do stowarzyszenia zajmującego się sporządzaniem opinii ze specjalności, co do której wnosił on o wpis na listę.

Jak wynika z powyższego, przepisy prawa, zapewne pomimo takiego zamiaru ustawodawcy, nie odnoszą się wyczerpująco do sytuacji życiowych każdego z kandydatów na biegłych. Istnieje ryzyko, że kandydat niezatrudniony nie przedstawi opinii pracodawcy lub organizacji. W takim przypadku, przy braku wypracowania dobrego wzorca postępowania, prezes sądu faktycznie pozbawiony jest możliwości prześledzenia dotychczasowego przebiegu zatrudnienia kandydata, a co za tym idzie - jego historii i rokowań na przyszłość. Opinia pracodawcy lub organizacji znającej kandydata jest cennym źródłem informacji o jego osobie. Wobec tego warto podnieść postulat unormowania tej sytuacji przez ustawodawcę. W przypadku braku zatrudnienia lub wykonywania wolnego zawodu przez kandydata warto byłoby rozważyć postawienie kandydatowi wymogu przedstawienia opinii byłego pracodawcy lub stowarzyszenia zrzeszającego kandydata.

\section{Wiedza teoretyczna i umiejętności praktyczne}

Najtrudniejszym zadaniem, jakie stoi przed prezesem oceniajacym kandydaturę potencjalnego biegłego, jest niewątpliwie ocena, czy kandydat posiada teoretyczne i praktyczne wiadomości specjalne warunkujace wykonywanie przez niego funkcji biegłego z danej dziedziny wiedzy. Wypracowany przez Prezesa Sądu Okręgowego w Poznaniu model oceny kwalifikacji kandydatów na biegłych wypełnia obecnie istniejaccą lukę w przepisach prawa i wychodzi naprzeciw oczekiwaniom weryfikujacych kwalifikacje kandydatów na biegłych. Z tego względu wart jest przedstawienia. Obecnie trwa spór pomiędzy środowiskami prawniczymi a częścią środowisk biegłych odnośnie 
do ostatecznego kształtu ustawy o biegłych sądowych. Biegli przekonuja, że obecny system weryfikacji wiedzy i umiejętności kandydatów na biegłych jest wystarczajaccy. Bronią się tym samym przed wprowadzeniem swego rodzaju organu złożonego ze specjalistów z poszczególnych dziedzin wiedzy, którego zadaniem byłaby ocena wiedzy i umiejętności kandydatów ${ }^{24}$. Faktem jednak jest, że bez pomocy specjalistów z danej dziedziny, z której ustawania się kandydata biegłym, prezes sądu nie jest w stanie ocenić kwalifikacji merytorycznych kandydata. Nikt, kto nie jest specjalistą z danej dziedziny, nie jest w stanie tego zrobić. Dlatego też tym bardziej warto wskazać na ów (wypracowany w okręgu poznańskim) model oceny kwalifikacji kandydatów na biegłych sądowych.

Dla oceny teoretycznych wiadomości specjalnych warunkujących podjęcie przez kandydata funkcji biegłego z danej dziedziny wiedzy konieczne jest:

1) ustalenie poziomu wykształcenia kandydata;

2) ustalenie rodzaju wykształcenia kandydata;

3) ustalenie rodzaju wykształcenia uzupełniającego kandydata.

Nie ulega wątpliwości, że w przypadku kandydatów na biegłych sądowych z dziedziny kryminalistyki kandydaci ci powinni posiadać wykształcenie co najmniej wyższe ${ }^{25}$. Co prawda ustawodawca nie precyzuje poziomu wykształcenia kandydata na biegłego, jednakże trudno wyobrazić sobie biegłego kryminalistyka bez wyższego wykształcenia i dodatkowo o kierunku korespondującym z dziedzina, w której kandydat ma być ustanowiony biegłym ${ }^{26}$. Studia wyższe kształtują nie tylko postawę kandydata, ale też i umożliwiają mu nabycie wiedzy, której nie gwarantuje szkoła zawodowa lub średnia, zwłaszcza o profilu ogólnym.

Rodzaj wykształcenia pokrewny z dziedzina wiedzy, z której kandydat ma być ustanowiony, wydaje się, że jest warunkiem nieodzownym w ustaleniu, iż kandydat posiada kwalifikacje do pełnienia funkcji biegłego z danej dziedziny. Co prawda nie można wykluczyć, że humanista z wykształcenia będzie dobrym ekspertem z dziedziny wymagajacej wiedzy z zakresu nauk ścisłych, jednakże niewątpliwie zasadą powinno być, aby biegły posiadał wy-

${ }^{24}$ Na ostatniej z cyklu XIV Konferencji Biegłych Sądowych, która odbyła się 21-22 kwietnia 2016 r. w Częstochowie, Romuald Tomczyk, Prezes Stowarzyszenia Rzeczoznawców Ekonomicznych w Częstochowie, wyrażał pogląd, że obecnie obowiązujące przepisy prawa zakładające ocenę kwalifikacji kandydata na biegłego na podstawie przedłożonych przez niego dokumentów jest wystarczające i zbędne jest powoływanie organu weryfikującego. Wskazywał on na swoje obawy odnośnie do możliwości powstawania zależności osobowych pomiędzy ocenianymi a oceniającymi. Autorka referatu była uczestnikiem tej konferencji. Zob. Program Czternastej (XIV) Krajowej Konferencji Biegłych Sądowych, http://www.sadowibiegli.pl/aktual/2016/14progr1.pdf [dostęp: 26.04.2016].

${ }^{25}$ Warunek poziomu wykształcenia nie musi być jednak spełniony odnośnie do każdej dziedziny wiedzy czy specjalności. Trudno wszakże wymagać od specjalistki w zakresie fryzjerstwa wykształcenia wyższego. Każdorazowo jednak poziom wykształcenia powinien być sprecyzowany odnośnie do kandydata na biegłego z danej dziedziny.

${ }^{26}$ Pogląd taki co do kandydatów na biegłych z zakresu badań pismo znawczych wyraził prof. dr hab. Mirosław Owoc, wydając opinię co do jednego z kandydatów na biegłego sądowego z tej dziedziny wydaną na prośbę Prezesa Sądu Okręgowego w Poznaniu. 
kształcenie o kierunku korespondującym z dziedzina, z której jest ustanowiony biegłym.

Wiedza zdobyta przez kandydata $\mathrm{w}$ trakcie studiów wyższych może być przez kandydata na biegłego uzupełniona wiedzą zdobytą w trakcie kursów zawodowych lub szkoleń specjalistycznych. Obecnie brak jest szczegółowych wytycznych ustawodawcy co do wymagań merytorycznych stawianych kursom i szkoleniom, które mogą odbywać kandydaci na biegłych i które podnoszą poziom ich wiedzy w stopniu wystarczającym do pełnienia funkcji biegłego. W konsekwencji, przynajmniej w teorii, kandydat na biegłego może dysponować dyplomem ukończenia szkolenia jednodniowego, jak i kilku lub kilkunastodniowego, i to o różnym poziomie przekazywanej wiedzy. W praktyce możliwe jest też ukończenie przez kandydata na biegłego studiów podyplomowych uzupełniających poziom wiedzy kandydata.

Poziom oraz rodzaj wykształcenia biegłych wpisanych na listę biegłych sądowych ze specjalności daktyloskopia, traseologia, mechanoskopia i rekonstrukcja wypadków drogowych, badania chemiczne oraz badania biologiczne przedstawia tabela 2 .

Poziom oraz rodzaj wykształcenia biegłych ze specjalności badania dokumentów oraz fonoskopijne badania odsłuchowe przedstawia tabela 3.

Jak wynika z danych zawartych w tabeli 2 i 3 , zdarzały się przypadki posiadania przez biegłych wykształcenia niekorespondującego ze specjalnościa, w której ustanowieni byli biegłymi. Większość biegłych jednak takie wykształcenie posiadała.

Jak wskazano powyżej, obok wykształcenia podstawowego kandydata na biegłego ważne jest wykształcenie uzupełniające. Wykształcenie uniwersyteckie zapewnia kandydatowi na biegłego zasób wiedzy będący podstawą do dalszej edukacji w zakresie konkretnej dziedziny kryminalistyki. Specyfika kryminalistyki - brak szkół kształcących specjalistów z poszczególnych dziedzin wiedzy - wymaga kierunkowego dokształcenia. Problemem jest tutaj źródło wiedzy. Brak szkół zajmujących się kształceniem np. ekspertów pismoznawców. W dalszym ciagu efektywną formą nauki i tym samym zdobycia wiedzy i praktyki jest nauka pobierana u innego eksperta $\mathrm{z}$ tej samej dziedziny.

Kandydaci na biegłych, ubiegając się o wpis na listę prowadzoną przez Prezesa Sądu Okręgowego w Poznaniu, przedkładali trzy rodzaje dokumentów:

1) świadectwa/certyfikaty odbytych kursów i szkoleń;

2) świadectwa ukończenia studiów podyplomowych;

3) świadectwa kwalifikacji uprawniajace do wydawania opinii w policyjnych laboratoriach kryminalistycznych ${ }^{27}$.

Zestawienie dokumentów przedkładanych przez kandydatów na biegłych przedstawia tabela 4 .

${ }^{27}$ Wydawane na podstawie zarządzenia Nr 3 Komendanta Głównego Policji z 17 stycznia 2014 r. w sprawie uprawnień do wydawania opinii oraz wykonywania czynności w policyjnych laboratoriach kryminalistycznych (Dz. Urz. KGP 2014.7). 


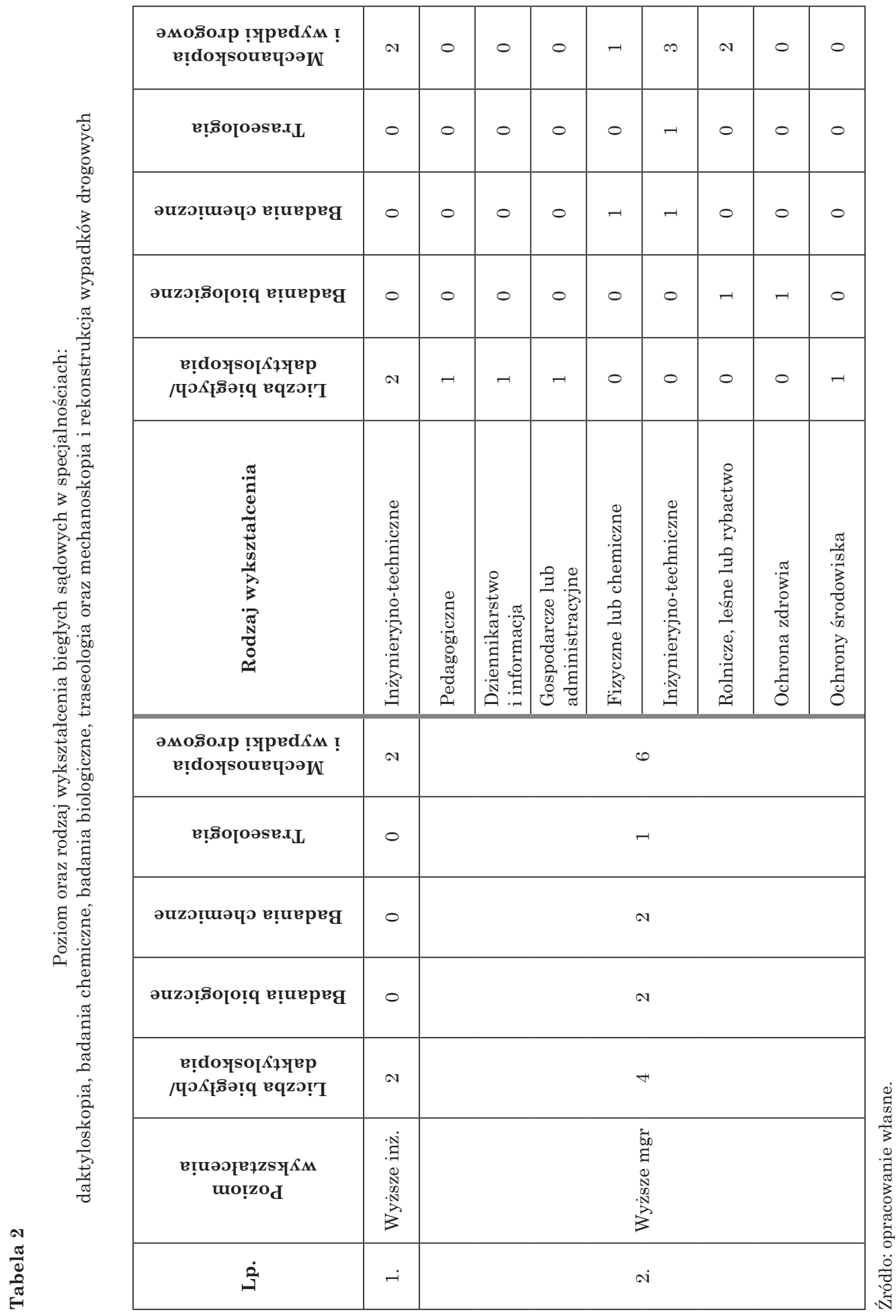




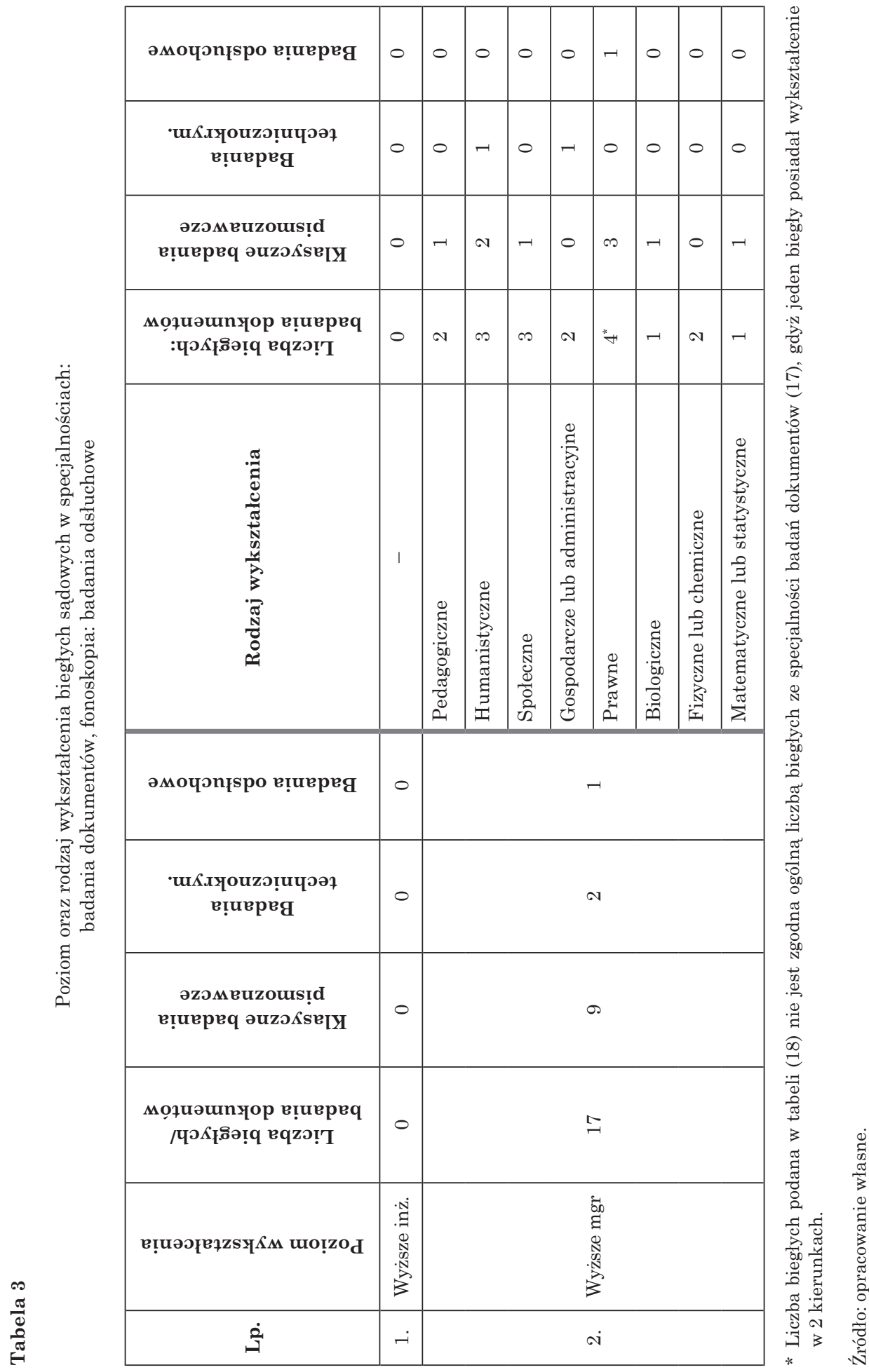


Jak wynika z tabeli 4, większość biegłych na potwierdzenie posiadanych przez siebie wiadomości teoretycznych przedłożyła świadectwa kwalifikacji uprawniajace do wydawania opinii w policyjnych laboratoriach kryminalistycznych. Część biegłych przedłożyła ponadto dyplomy ukończenia studiów podyplomowych. Jak wskazano jednakże powyżej, brak wartościowania szkoleń i kursów dla kandydatów na biegłych uniemożliwia obecnie realną ocenę poziomu wiedzy kandydata ze strony osoby nieposiadajaccej wiedzy co do poziomu szkolenia na poszczególnych szkoleniach, kursach, czy nawet studiach podyplomowych.

Tabela 4

Dokumenty przedkładane przez kandydatów na biegłych

\begin{tabular}{|c|c|c|c|c|c|c|c|c|}
\hline Lp. & $\begin{array}{r}\text { Specjalnośćl } \\
\text { Liczba przypadków }\end{array}$ & 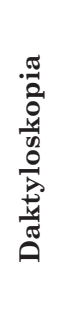 & 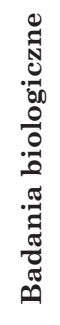 & 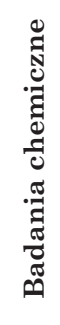 & 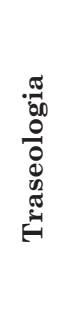 & 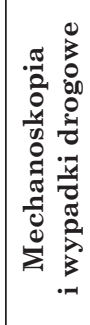 & 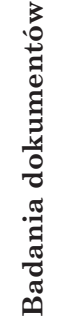 & 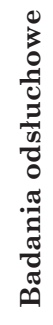 \\
\hline 1. & $\begin{array}{l}\text { Świadectwo kwalifikacji uprawniające do } \\
\text { wydawania opinii } \\
\text { w policyjnych laboratoriach } \\
\text { kryminalistycznych }\end{array}$ & 6 & 2 & 2 & 1 & 7 & 10 & 1 \\
\hline 2 & $\begin{array}{l}\text { Świadectwo ukończenia Studium } \\
\text { Oficerskiego Ekspertów Kryminalistyki } \\
\text { Wyższej Szkoły Policji w Szczytnie }\end{array}$ & 2 & 0 & 0 & 0 & 0 & 0 & 0 \\
\hline 3 & $\begin{array}{l}\text { Świadectwo ukończenia Wyższego } \\
\text { Zawodowego Studium Prawno- } \\
\text {-Administracyjnego oraz Ochrony } \\
\text { Bezpieczeństwa i Porzadku Publicznego } \\
\text { Wyższej Szkoły Oficerskiej w Szczytnie }\end{array}$ & 1 & 0 & 0 & 0 & 0 & 0 & 0 \\
\hline 4 & $\begin{array}{l}\text { Dyplom ukończenia Podyplomowego } \\
\text { Studium Ekspertyzy Dokumentów, } \\
\text { Uniwersytet Wrocławski }\end{array}$ & 0 & 0 & 0 & 0 & 0 & 5 & 0 \\
\hline 5. & $\begin{array}{l}\text { Dyplom ukończenia studiów } \\
\text { podyplomowych Akademii } \\
\text { Polonijnej w Częstochowie, Wydział } \\
\text { Interdyscyplinarny Ekspertyza } \\
\text { Dokumentów }\end{array}$ & 0 & 0 & 0 & 0 & 0 & 1 & 0 \\
\hline 6. & $\begin{array}{l}\text { Świadectwo ukończenia studium } \\
\text { podyplomowego z zakresu } \\
\text { kryminalistycznej rekonstrukcji wypadków } \\
\text { drogowych }\end{array}$ & 0 & 0 & 0 & 0 & 1 & 0 & 0 \\
\hline 7. & $\begin{array}{l}\text { Dokumenty potwierdzajace uzyskanie } \\
\text { tytułu profesora nauk prawnych w zakresie } \\
\text { prawa }\end{array}$ & 0 & 0 & 0 & 0 & 0 & 1 & 0 \\
\hline
\end{tabular}


cd. tab. 4

\begin{tabular}{|c|l|c|c|c|c|c|c|c|}
\hline 8. & $\begin{array}{l}\text { Świadectwo ukończenia kursu } \\
\text { specjalistycznego techniki } \\
\text { kryminalistycznej realizowanego przez } \\
\text { Centrum Szkolenia Policji w Legionowie }\end{array}$ & 1 & 0 & 0 & 0 & 0 & 0 & 0 \\
\hline 9. & $\begin{array}{l}\text { Potwierdzenie otrzymania uprawnień } \\
\text { rzeczoznawcy zweryfikowanego przez } \\
\text { Stowarzyszenie Rzeczoznawców Techniki } \\
\text { Samochodowej i Ruchu Drogowego }\end{array}$ & 0 & 0 & 0 & 0 & 0 & 0 & 0 \\
\hline 10. & $\begin{array}{l}\text { Dyplom mistrza w rzemiósle mechanika } \\
\text { pojazdowa }\end{array}$ & 0 & 0 & 0 & 0 & 1 & 0 & 0 \\
\hline 11. & $\begin{array}{l}\text { Dyplomy potwierdzajacce odbycie szeregu } \\
\text { szkoleń w zakresie komputerowej kalkulacji } \\
\text { szkód powypadkowych, elementów budowy } \\
\text { silników samochodowych }\end{array}$ & 0 & 0 & 0 & 0 & 1 & 0 & 0 \\
\hline 12. & $\begin{array}{l}\text { Certyfikaty potwierdzające odbycie szkoleń } \\
\text { tematycznych krajowych i zagranicznych } \\
\text { (w języku obcym) m.in. co do zabezpieczenia } \\
\text { śladów biologicznych }\end{array}$ & 0 & 1 & 0 & 0 & 0 & 0 & 0 \\
\hline
\end{tabular}

Źródło: opracowanie własne.

Ocena poziomu wiedzy kandydata jest zadaniem trudnym. Jednakże o wiele trudniejsze jest dokonanie oceny posiadania przez kandydata umiejętności praktycznych niezbędnych do pełnienia funkcji biegłego. Zestawienie sposobów weryfikacji umiejętności praktycznych kandydatów na biegłych sądowych wypracowanych przez Prezesa Sądu Okręgowego w Poznaniu przedstawia tabela 5 .

Tabela 5

Sposoby weryfikacji umiejętności praktycznych kandydatów na biegłych

\begin{tabular}{|c|l|c|l|}
\hline Lp. & \multicolumn{1}{|c|}{ Sposób weryfikacji } & $\begin{array}{c}\text { Liczba } \\
\text { przypadków* }\end{array}$ & \multicolumn{1}{c|}{ Uwagi } \\
\hline 1. & $\begin{array}{l}\text { Przedłożenie świadectwa } \\
\text { uprawniającego do wydawania } \\
\text { opinii w policyjnych laboratoriach } \\
\text { kryminalistycznych Policji }\end{array}$ & 21 & Stosowany samodzielnie \\
\hline 2. & $\begin{array}{l}\text { Pisemny pozytywny wywiad } \\
\text { przeprowadzony u organów } \\
\text { postępowania przygotowawczego } \\
\text { oraz w sądach }\end{array}$ & $\begin{array}{l}\text { Stosowany samodzielnie; } \\
\text { pozytywne opinie } \\
\text { co do terminowości } \\
\text { i bezproblemowości } \\
\text { współpracy z ekspertem } \\
\text { ad hoc lub ustanowionym } \\
\text { biegłym w innym okręgu } \\
\text { sądowym }\end{array}$ \\
\hline
\end{tabular}




\begin{tabular}{|c|c|c|c|}
\hline 3. & $\begin{array}{l}\text { Pisemna rekomendacja } \\
\text { prowadzacych postępowanie } \\
\text { przygotowawcze lub sądowe }\end{array}$ & 2 & $\begin{array}{l}1 \text { przypadek - stosowany } \\
\text { samodzielnie } \\
1 \text { przypadek - pomimo } \\
\text { rekomendacji Prezes } \\
\text { zwrócił się z wnioskiem } \\
\text { o zaopiniowanie kandydata } \\
\text { przez innego biegłego } \\
\text { sądowego }\end{array}$ \\
\hline 4. & $\begin{array}{l}\text { Pisemna pozytywna opinia innego } \\
\text { biegłego }\end{array}$ & 4 & $\begin{array}{l}\text { Stosowany samodzielnie; } \\
1 \text { przypadek - na wniosek } \\
\text { Prezesa } \\
3 \text { przypadki - biegli } \\
\text { przedłożyli opinie } \\
\text { samodzielnie }\end{array}$ \\
\hline 5. & $\begin{array}{l}\text { Pisemna pozytywna opinia } \\
\text { stowarzyszeń rzeczoznawców } \\
\text { w danej specjalności }\end{array}$ & 4 & $\begin{array}{l}2 \text { przypadki - stosowany } \\
\text { samodzielnie; każdorazowo } \\
\text { na wniosek Prezesa } \\
2 \text { przypadki - stosowany } \\
\text { łącznie ze sposobem ad } 2 \text {, na } \\
\text { wniosek Prezesa }\end{array}$ \\
\hline 6. & Brak weryfikacji & 2 & $\begin{array}{l}1 \text { przypadek - przedłożenie } \\
\text { przez kandydata } \\
\text { potwierdzenia posiadania } \\
\text { tytułu profesora nauk } \\
\text { prawnych w zakresie prawa } \\
2 \text { przypadki - wieloletni } \\
\text { biegły }\end{array}$ \\
\hline
\end{tabular}

* Liczba przypadków (37) nie jest zgodna z ogólną liczbą biegłych (35), gdyż 2 biegłych posiadało jednocześnie 2 specjalności.

Źródło: opracowanie własne.

Jak wynika z tabeli 5, Prezes Sądu Okręgowego w Poznaniu wypracował 5 sposobów weryfikacji. Stosowane były one samodzielnie lub w połączeniu ze sobą w różnych konfiguracjach. Ocena poziomu umiejętności praktycznych kandydata dokonywana w sposób 2 i 3 dotyczyła oceny formalnej jakości pracy kandydata. Co do sposobu 4 weryfikacji warto wskazać, że dotyczył on w większości osób, które stosunkowo niedawno - w ciagu kilku ostatnich lat - zostały wpisane na listę biegłych sądowych. W opiniach o kandydatach rekomendujący odnosili się do poziomu merytorycznego pracy kandydatów, gdyż często zdarzało się, że brali oni udział w sporządzaniu opinii pod kierunkiem tych biegłych. Praktyka ta jest o tyle warta uwagi, że - jak wynika z powyższego - sami biegli widzą potrzebę wykazania wysokiego poziomu umiejętności na podstawie opinii innego biegłego już uznanego przez sąd. Przy obecnej regulacji prawnej brak możliwości innego sposobu weryfikacji umiejętności kandydata na biegłego jak przy pomocy specjalistów z danej dziedziny.

Warto wskazać, że zdarzało się, iż kandydaci na biegłych, ubiegając się o wpis na listę prowadzona przez Prezesa Sądu Okręgowego w Poznaniu, 
przedkładali poświadczenie wpisania ich na listę innego sądu. Nie zdarzyło się jednak, aby ów fakt uznano za wystarczajacy do dokonania wpisu na listę.

Jak wynika z powyższej analizy, praktyka - pomimo braku szczegółowych uregulowań prawnych w tym zakresie - wypracowała taki model postępowania, który umożliwia dokonanie realnej oceny poziomu wiedzy i umiejętności praktycznych kandydata na biegłego sądowego. Co do przyjętego modelu weryfikacji - przez zasięganie opinii specjalistów oraz organów postępowania, które miały styczność z kandydatem na biegłego w trakcie jego pracy - warto wysunać postulat usprawnienia przyjętego sposobu oceny poprzez umożliwienie udostępnienia oceniającym opinii już wydanych przez kandydatów. Sama informacja o terminowości sporządzania opinii i brak problemów we współpracy z biegłym jest ważna. Nie zastapi ona jednak realnej merytorycznej oceny poziomu wiedzy i umiejętności kandydata dokonanej nie inaczej jak na podstawie wyników jego pracy. Badania co do sposobu weryfikacji przeprowadzono na podstawie postępowań prowadzonych w odniesieniu do biegłych z dziedziny kryminalistyki. Wiadomo jest jednocześnie autorce, że w odniesieniu do kandydatów na biegłych innych specjalności zdarzały się już przypadki zlecenia opiniujacym dokonania merytorycznej oceny wyników pracy kandydatów na biegłych w postaci opinii.

\section{WNIOSKI I POSTULATY}

Przeprowadzona w ramach niniejszego artykułu analiza pozwoliła na wyprowadzenie następujących wniosków i przedstawienie następujacych postulatów:

1) Obecnie nie ma realnych możliwości weryfikacji spełnienia przez kandydata warunku posiadania pełni praw cywilnych i obywatelskich. W szczególności brak centralnego rejestru pozwalającego na ustalenie, czy kandydat posiada pełną zdolność do czynności prawnych.

2) W przypadku kandydata niezatrudnionego i niewykonujaceego wolnego zawodu nie ma obowiązku pozyskiwania opinii o kandydacie. Istnieje zatem ryzyko, że nie będzie możliwa ocena, czy kandydat daje gwarancję należytego wykonywania obowiązków biegłego. Lukę tę można uzupełnić obowiązkiem przedstawienia przez kandydata opinii organizacji/stowarzyszenia prowadzącego działalność w tożsamej dziedzinie, z której kandydat ubiega się o ustanowienie biegłym.

3) Ustawodawca nie precyzuje specjalności wykształcenia biegłego z danej dziedziny wiedzy. W konsekwencji może zdarzyć się, że kandydat na biegłego nie będzie legitymował się wykształceniem kierunkowym.

4) Obecnie brak kompleksowych uregulowań co do modelu weryfikacji poziomu wiedzy merytorycznej i umiejętności praktycznych kandydata. Istniejacy model jest niepełny i przy braku odpowiedniej praktyki ze strony prezesa sądu może prowadzić do niepożądanych skutków, czyli do ustanowienia biegłym osoby bez odpowiednich kwalifikacji. 
5) Prezes Sądu Okręgowego w Poznaniu wypracował pięć sposobów weryfikacji umiejętności praktycznych oraz - siłą rzeczy - teoretycznych kandydatów na biegłych sądowych. Stosowane są one samodzielnie lub w połączeniu ze soba, i to w różnych konfiguracjach. Merytoryczna ocena umiejętności biegłego każdorazowo wspomagana była oceną praktyków z tej samej dziedziny lub prowadzących postępowanie przygotowawcze lub sądowe w sprawach, w których kandydat wydał opinię. Tym samym praktyka weryfikacji poziomu wiedzy i umiejętności kandydatów na biegłych z dziedziny kryminalistyki wypracowana przez Prezesa Sądu Okręgowego w Poznaniu wychodzi naprzeciw realnym potrzebom wymiaru sprawiedliwości odnośnie do oceny kwalifikacji kandydatów na biegłych sądowych.

Z powyższych względów praktyka weryfikacji poziomu wiedzy i umiejętności kandydatów na biegłych wypracowana przez Prezesa Sądu Okręgowego w Poznaniu warta jest nie tylko uwagi, ale i wdrożenia ze strony ustawodawcy tak, ażeby zapewnić jednolitość sposobu postępowania co do weryfikacji kandydatur na biegłych na terenie całego kraju. Tym samym postulowany od lat sposób weryfikacji kandydatów na biegłych sądowych w okręgu poznańskim stał się rzeczywistością. Rzeczywistością godną naśladowania.

dr Matgorzata Hrehorowicz

Uniwersytet im. Adama Mickiewicza w Poznaniu

mhrehor@amu.edu.pl

\author{
VERIFICATION OF CANDIDATES FOR COURT EXPERTS \\ IN FORENSICS ON THE EXAMPLE OF THE PRACTICE DEVELOPED \\ AT THE DISTRICT COURT IN POZNAN
}

Summary

This article aims to establish the current practice of determining the qualifications of candidates for court experts. This is done on the example of the model developed by the District Court in Poznan on the basis of the author's research. The study involved examination of personal files of court experts in forensics entered in the list kept by the President of the District Court in Poznan. First, the standard model for determining the qualifications of candidates for expert witnesses adopted by statute has been presented, and then the qualifications of expert witnesses from the list and the manner of their documentation by candidates examined. This is followed by an analysis of the manner in which the qualifications of candidate experts are verified by the President of the District Court in Poznan. 
